نكاتى در مورد جند كونه از سرده Glaucium (تيره شقايقيان) در ايران

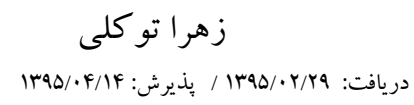

$$
\text { كروه علوم گياهى، دانشكده علوم زيستى، دانشخاه خوارزمى، تهران، ايران }
$$

tavakoli@khu.ac.ir :

$$
\begin{aligned}
& \text { جكيده. در راستاى بازنخرى جنس Glaucium، contortuplicatum var. hirsutum به عنوان واريته جديد معرفى مى گردد. اين واريته با داشتن }
\end{aligned}
$$

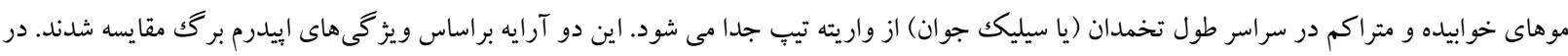

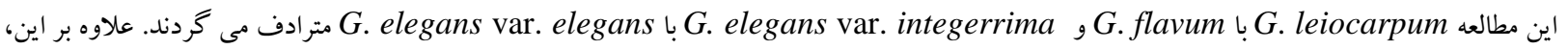

$$
\begin{aligned}
& \text { ويزگى هاى ريخت شناسى و يراكنش جغر افيايى آرايه هاى مطالعه شده در ايران و جهان بيان مى شوند } \\
& \text { وازههاى كليدى. آرايهشناسى، آناتومى برگى، متر ادفهاى جديد، واريته جديد }
\end{aligned}
$$

\title{
Notes on some species of the genus Glaucium (Papaveraceae) in Iran
}

\author{
Zahra Tavakkoli \\ Received: 18.05.2016 / Accepted: 04.07.2016
}

Department of Plant Sciences, Faculty of Biological Sciences, Kharazmi University, Postal Code 15719-14911, Tehran, Iran

Email: tavakoli@khu.ac.ir

\begin{abstract}
During the taxonomic revision of the genus Glaucium, G. contortuplicatum var. hirsutum is described as a new variety. This taxon differs from the type variety by having dense and appressed trichomes all along ovary (or junior silique). Leaf epidermis micro-characters of these two taxa are also compared. G. leiocarpum and G. elegans var. integerrima are reduced to synonymy of $G$. flavum and G. elegans var. elegans, respectively. Additionally, morphological characters and geographical distribution of the taxa studied in the world and in Iran are presented.
\end{abstract}

Keywords. leaf anatomy, new synonyms, new variety, taxonomy

\section{INTRODUCTION}

The Papaveraceae comprises three subfamilies: Papaveroideae Ernst, Eschschozioideae Ernst and Chelidonoideae Ernst. The family is widely distributed in temperate and subtropical regions of the Northern hemisphere, especially the Mediterranean, western, central and eastern Asia and south western parts of the USA, extending to north of South America (Takhtajan, 2009). According to the molecular studies of Hoot et al., (1997) Eschscholzioideae is sister group to Papaveroideae and
Chelidonoideae (including Glaucium and Dicranostigma). Glaucium Miller consists of 23 species worldwide (Kadereit, 1993) and 12 species in Flora Iranica area (Cullen, 1966). The genus was divided into 13 taxa in Iran (Cullen, 1966) including 11 species and two subspecies, while the number of taxa was increased to 21 with 13 species, 6 sub species and two varieties by (Mobayen, 1985).

Of the species distributed in Iran, five species are 

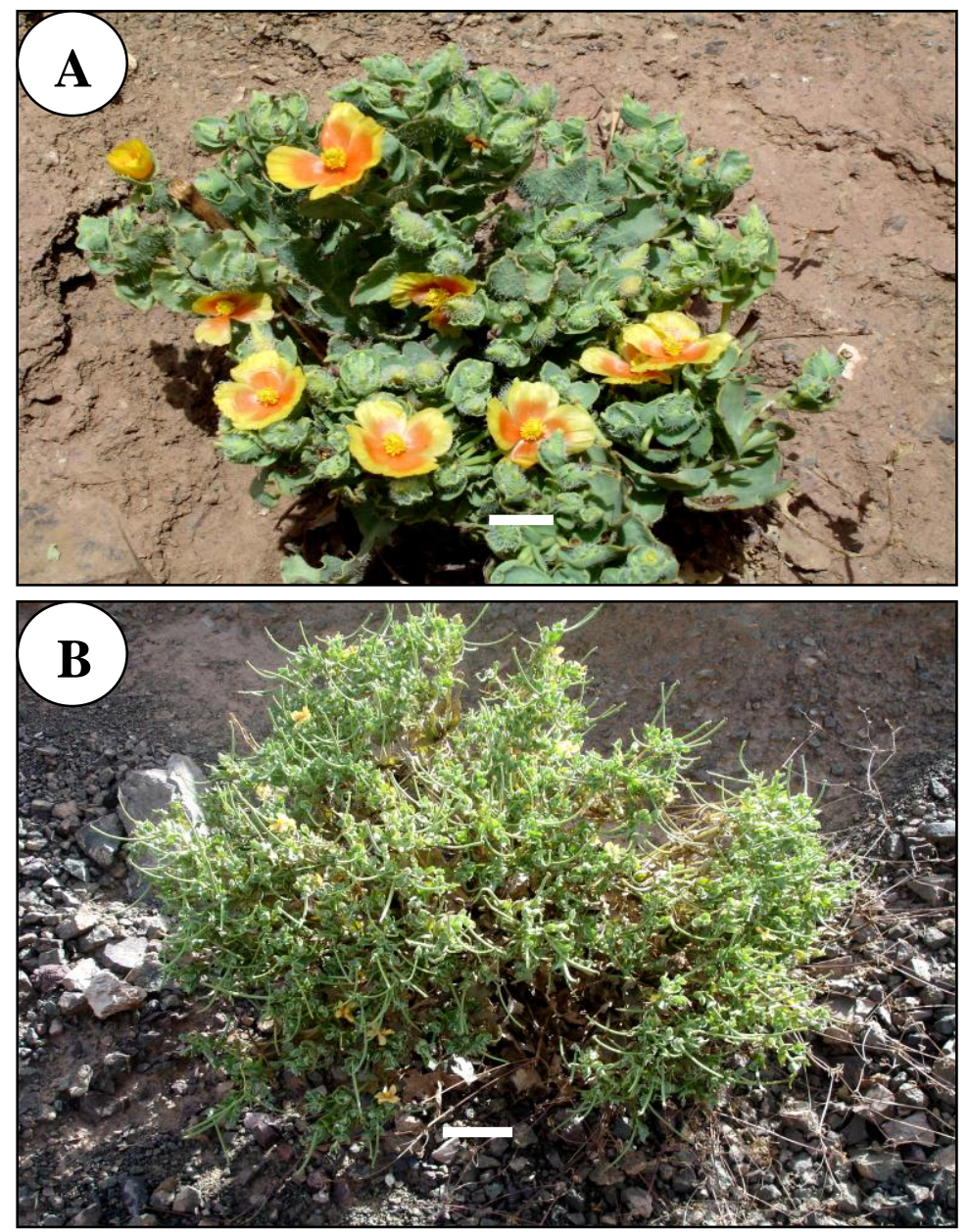

Fig. 1. Photographs of Glaucium contortuplicatum var. hirsutum. A: scale bar $=2 \mathrm{~cm} ; \mathbf{B}$ : scale bar $=7 \mathrm{~cm}$.

endemics: including G. contortuplicatum Boiss., G. calycinum Boiss., G. elegantissimum Mobayen, G. mathiolifolium Mobayen and G. golestanicum Gran \& Sharifnia (Mobayen, 1985; Gran \& Sharifnia, 2008).

G. leiocarpum Boiss. was distiguished as a distinct species by Mory (1979), Cullen (1965), Mowat (1964) and Mobayen (1985), whereas Cullen (1966) reduced it as the synonym of $G$. oxylobum Boiss. \& Buhse.

Mobayen (1985) described G. elegans by the variety integerrima whereas this species is divided into one subspecies and two varieties from Iran by Mory (1979), i.e. G. elegans subsp. elegans var. elegans and var. bornmulleri Fedde.

Parsa (1986) and Fedde (1909) introduced this species only with var. bornmulleri.

The present study aims to describe a new variety of $G$. contortuplicatum and investigate the taxonomic status of G. leiocarpum and G. elegans var. integerrima.

\section{MATERIAL AND METHODS}

This study is mainly based on specimens collected in their flowering and fruiting stages from different parts of Iran and herbarium plant materials of TARI, FAR, T and IRAN. Observations and relevant literature have been employed for taxonomic descriptions (Cullen, 1966; Mory, 1979; Mobayen, 1985; Boissiera, 1867). Mature leaves were selected and preserved in glycerin-ethanol (1:1) for about 72 hours, then transferred to $70 \%$ ethanol. The epidermis of the leaves was removed from the midlamina part of adaxial and abaxial surfaces and after being stained with $0.1 \%$ fushin, the samples were mounted in glycerin jelly.

The slides were observed by means of Jenus light microscope at $\times 400$ magnification and more than sixty epidermis photos were taken with a Nikon digital camera. For SEM investigations, sections were transferred to stubs, coated with gold for 5-6 minutes and photographed with xl-30 SEM. The terminology of epicuticular waxes and stomatal types follows Barthlott at al. (1998) and that of Van Cotthem (1970), respectively. 

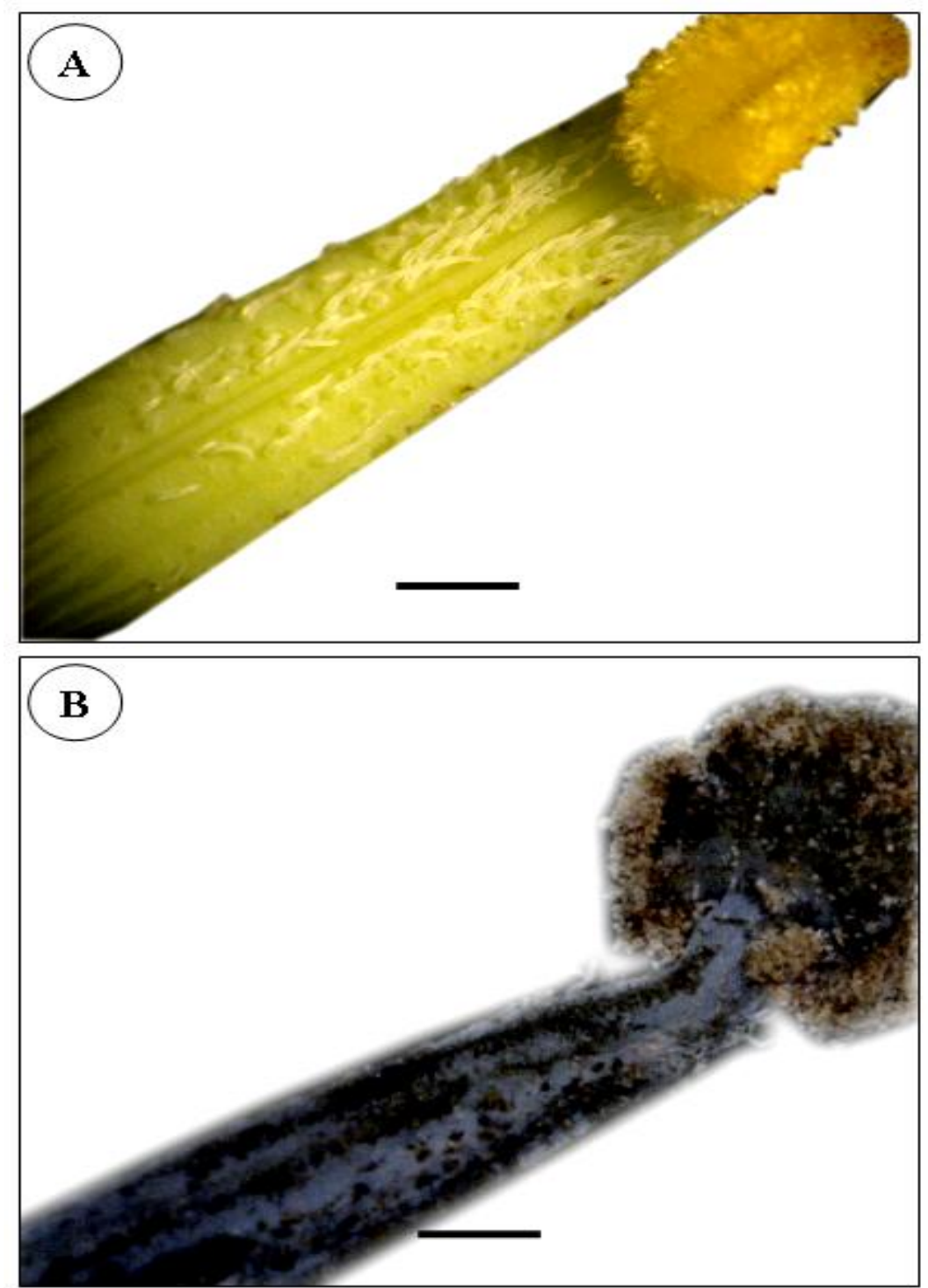

Fig. 2. Photographs of junior silique. A: G. contortupıcuıurn var. hirsutum; B: var. contortuplicatum. scale bar = $1 \mathrm{~mm}$.

\section{RESULTS AND DISCUSSION}

\section{Taxonomy}

G. contortuplicatum var. hirsutum Tavakkoli \& Assadi var. nov. (Fig. 1).

Type. Iran. Gilan: Qazvin Rasht road, $95 \mathrm{~km}$. Rasht, 520 m, 27 June 2013, Tavakkoli 54331 (holotypus FAR).

Diagnose. This variety is distinguished by possessing hairs all along junior silique, which are at the apex in type variety (Fig. 2). We found the specimens of var. hirsutum together with type variety in mixed population.

Description. Biennial herbs, $12-50 \mathrm{~cm}$ high. Stems green to purplish, glabrous or with sparsely crisp flattened hairs below, branching from lower part; branches opposite and corymbose. Basal leaves $4.5-23 \times 1-5 \mathrm{~cm}$, with crisped and scatter to rather dense hairs, lyrate-pinnatisect to pinnatipartite; the lower segments ovate or triangular, entire, acute; the upper segments broad oblong to elliptic, dentate or pinnatifid; the terminal segment broadly obovate, trilobed; lobes broad ovate or oblong, entire or dentate, acute and with apical hairs; petioles $1-5 \mathrm{~cm}$ long, ribbed, hairy and broadened at the base; stem leaves $0.5-22 \times 0.4-4 \mathrm{~cm}$, sessile to semi-amplexicaule, glabrous or with scattered to rather dense hairs; the upper and middle leaves broad ovate, broadly oblong to obovate, entire, dentate to pinnatifid; the terminal segment trilobed; lobes triangular, acute and with apical hairs; the lower leaves similar to basal leaves. Buds 8-17×3.5-7 mm, narrow ovate; sepals glabrous or covered with crisped and rather dense hairs. 

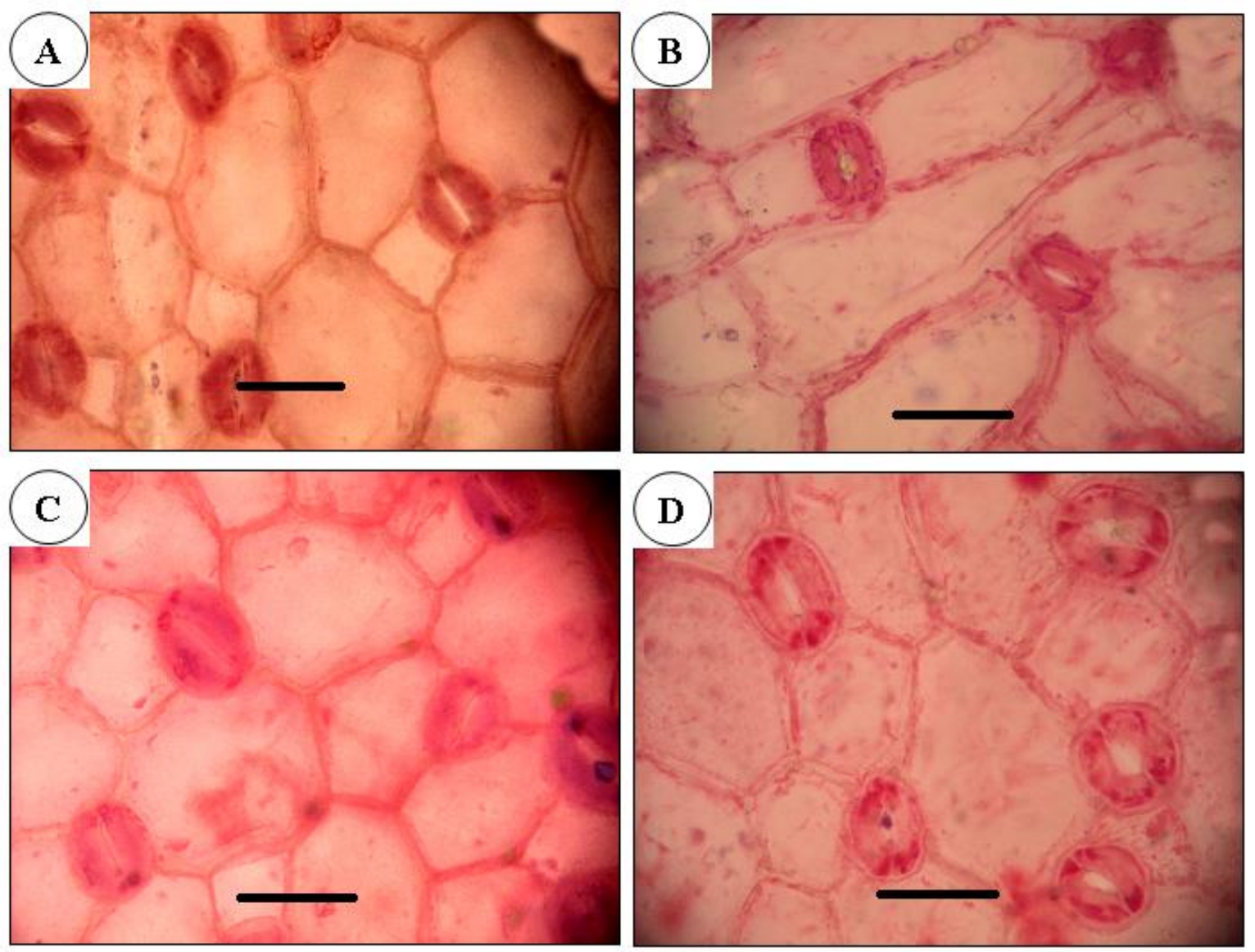

Fig. 3. LM micrographs of leaf epidermis in Glaucium contortuplicatum. A, B: var. hirsutum; C, D: var. contortuplicatum. A, C: adaxial surface; B, D: abaxial surface. scale bars $=50 \mu \mathrm{m}$.

Peduncle 2-6 cm long, hairy, erect, curved or contorted; petals $8-18 \times 7-17 \mathrm{~mm}$, broadly obovate, yellow and orange at the lower part, dentate at apical margin. Stamens shorter to longer than ovary; anthers 1-2 mm long, yellow, cylindrical to oblong; filaments monotonic and slender, sometimes broadened at the lower part, gradually towards the base, yellow and sometimes purple at the lower part. Junior silique covered with hair; hairs $0.13-0.82 \mathrm{~mm}$ long. Mature silique $6.5-18 \mathrm{~cm}$ lo$\mathrm{ng}$ and $1.5-4 \mathrm{~mm}$ in diameter; with remote hairs, torulose, contorted or strongly contorted; stigma 4-7 mm broad.

Phenology. Flowering and fruiting in late May to early July.

\section{Distribution. Endemic.}

Specimens seen. Iran. Gilan province: ManjilAliabad, 550 m, 24 May 1973, Sabeti 14761 (TARI); East Azarbayejan: Zanjan to Mianeh, 110 km after Zanjan, 1150-1200 m, 9 July 1991, Jamzad et al. 70349 (TARI); Tehran province: Ghom, Venarch, Manganese mine, $1240 \mathrm{~m}, 26$
June 2010, Tavakkoli 6366 (FAR) (Fig. 7).

Leaf anatomy The mean size of stomata of adaxial surface is $46.48 \quad(30.58-59.09) \times 34.15$ (26.14-44.84) $\mu \mathrm{m}$ in var. hirsutum and 48.23 $(35.28-69.08) \times 36.26(26.39-51.62) \mu \mathrm{m}$ in the type variety, whereas the mean size of stomata of abaxial surface is $44.65(32.44-74.23) \times 34.15$ (24.05-51.73) $\mu \mathrm{m}$ in var. hirsutum and 42.74 (27.71-61.59) $\times 34(24.43-51.4) \mu \mathrm{m}$ in type variety.

Both taxa have polygonum epidermal cells with straight-curved anticlinal walls on adaxial and abaxial surfaces. G. contortuplicatum var. hirsut$u m$ has an average density of 53.53 and 69.65 per $\mathrm{mm}^{2}$ for upper and lower surfaces, respectively; while it is 60.97 and 96.89 per square millimeter on adaxial and abaxial sides in type variety. Both taxa have stomatal types of anomocytic, anisocytic and brachyparacytic (Fig. 3). The cuticle of leaf in var. hirsutum is rugulate under SEM observations. It is covered with moderately granular wax on the upper epidermis while rather dense wax granules are observed on the cuticle of lower epidermis (Fig. 4 A-D). 

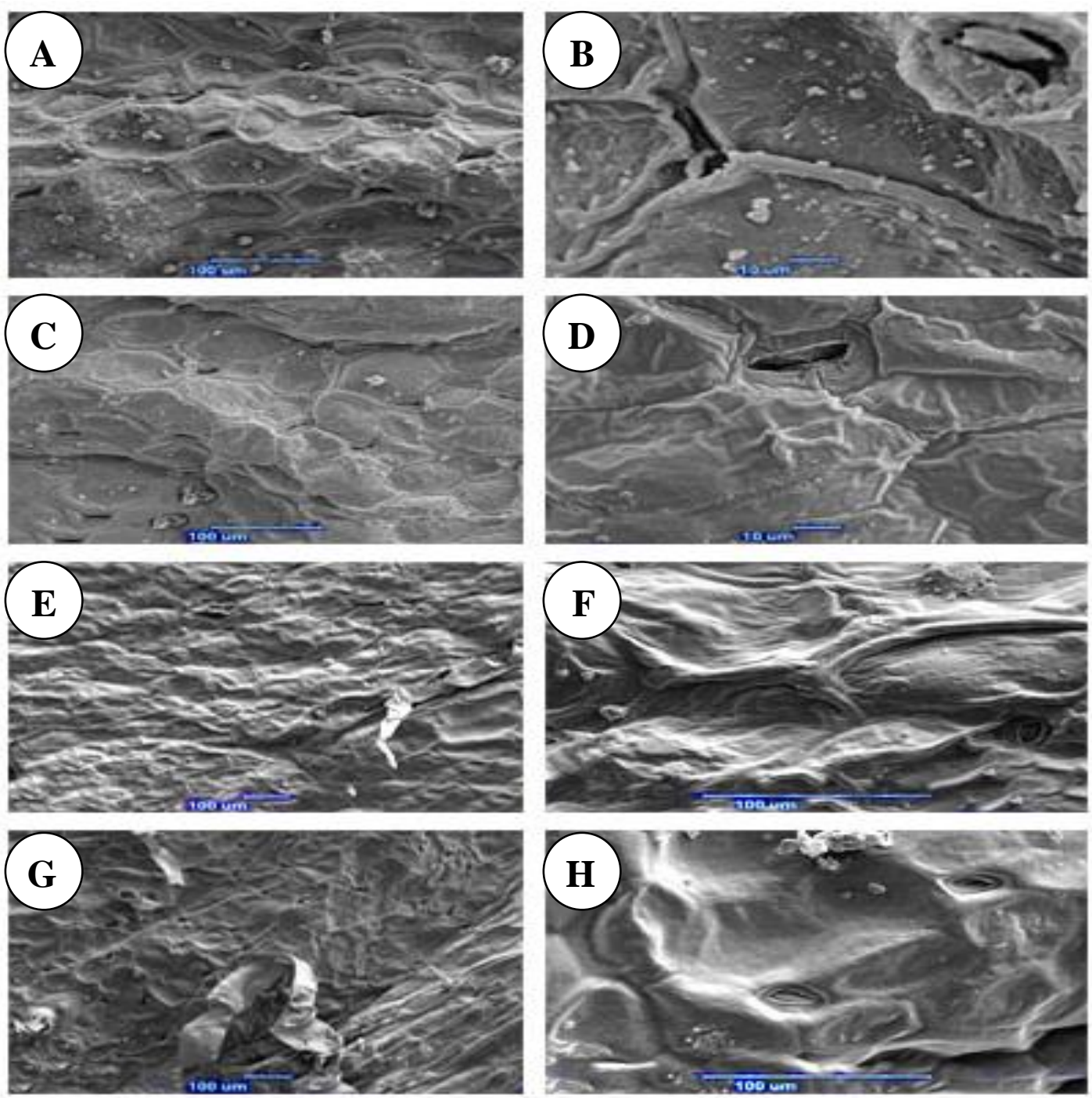

Fig. 4. SEM micrographs of leaf epidermis in Glaucium contortuplicatum. A-D: var. hirsutum; E-H: var. contortuplicatum. A, B, E, F: adaxial surface; C, D, G, H: abaxial surface.

The cuticle surface of var. contortuplicatum on the upper epidermis has fine striations and the cuticle surface on the lower surface is colliculate. Both cuticle surfaces are covered with scattered granular wax (Fig. 4 E-H).

\section{G. flavum Crantz, Austr. Ed. 1, 2: 133 (1763).} (Fig. 5).

Syn. G. leiocarpum Boiss., Fl. Or. 1: 122 (1867). Syn. nov.

Type. Greece: Attikí, Haussknecht, H.K. s.n. 1885, JE 00018895.

Description. Herbs biennial, $28-65 \mathrm{~cm}$ high, with one main stem or more. Stems erect, glabrous, light green to whitish, branching from lower part. Basal leaves 5-30×0.8-6 cm, with moderate to dense and crisped hairs; lyrate-pinnatisect to pinnapartite; the lower segments triangular, oblong to lanceolate, entire, acute and with apical hairs, the upper segments oblong, oblong to lanceolate, dentate or pinnatifid; lobes ovate or triangular, acute or obtuse and with apical hairs; the terminal segment broadly obovate, trilobed; the middle lobe ovate and entire; the lateral lobes nearly square, dentate; petioles $1.5-6 \mathrm{~cm}$ long, ribbed, hairy and broadened at the base; stem leaves $1-14 \times 0.5-5$ $\mathrm{cm}$, sessile, semi-amplexicaule, glabrous or with scattered hairs on the veins; the upper and middle leaves oblong to broad oblong, dentate, pinnatifid to pinnatisect; the segments oblong to lanceolate, triangular or ovate, acute or obtuse and with apical hairs; the terminal segment tri-lobed; lobes ovate or triangular, entire or sometimes dentate, acute or obtuse and with apical hairs; the lower leaves similar to basal leaves. Buds $0.8-3 \times 0.3-1 \mathrm{~cm}$, narrow ovate; sepals covered with scattered to rather dense and crisped hairs. Peduncle $0.4-5 \mathrm{~cm}$ long, erect. 
Table 1. Morphological differences between Glaucium. flavum and G. oxylobum.

\begin{tabular}{|c|c|c|}
\hline Characters & G. flavum & G. oxylobum \\
\hline Stem leaves & $\begin{array}{l}\text { Broadly oblong, pinnatifid to } \\
\text { pinnatisect. }\end{array}$ & $\begin{array}{l}\text { Oblong, broadly oblong or ovate, } \\
\text { crenate, lobed. }\end{array}$ \\
\hline Sepal & Covered with rather dense hairs. & Mostly glabrous. \\
\hline Petal color & $\begin{array}{l}\text { Yelow, yellow and orange at lower } \\
\text { part or reddish orange, with or } \\
\text { without violet basal spot. }\end{array}$ & $\begin{array}{l}\text { Deep red, yellow, orange red and with } \\
\text { black middle spot. }\end{array}$ \\
\hline Anther length & $1-3 \mathrm{~mm}$ long & $1-4 \mathrm{~mm}$ long \\
\hline Filament & $\begin{array}{l}\text { Monotonic at upper half and } \\
\text { gradually attenuate towards the } \\
\text { base }\end{array}$ & $\begin{array}{l}\text { Broadened at apex and gradually } \\
\text { towards the base }\end{array}$ \\
\hline Silique & $\begin{array}{l}8.5-19 \mathrm{~cm} \text { long and } 1.5-4 \mathrm{~mm} \text { in } \\
\text { diameter, not strongly thickened at } \\
\text { the base, erect or arcuate }\end{array}$ & $\begin{array}{l}8-26 \mathrm{~cm} \text { long and } 1.5-6 \mathrm{~mm} \text { in } \\
\text { diameter, strongly thickened at the } \\
\text { base, erect, arcuate or contorted }\end{array}$ \\
\hline Stigma & $2.5-5.5 \mathrm{~mm}$ broad & 3-8 mm broad \\
\hline
\end{tabular}

Petals $1.5-4 \times 1.3-4.5 \mathrm{~cm}$, broadly obovate to flabellate, yellow and without spot, yellow and orange at lower part or reddish orange and with basal violet spot; spots mostly with yellow margin. Stamens shorter to longer than ovary; anthers 1-3 $\mathrm{mm}$ long; filaments monotonic, gradually narrowed towards the base. Ovary covered with white tubercles or glabrous at lower part and sometimes tubercles near the apex. Mature silique $8-19 \mathrm{~cm}$ long and 1.5-4 $\mathrm{mm}$ in diameter, glabrous, rarely tuberculate, torulose or not, attenuate at the apex; stigma $2.5-5.5 \mathrm{~mm}$ broad.

Phenology. Flowering in May and fruiting in June to August.

Distribution. C. Europe, W. Caucasia, Turkey, Iran and N. W. Africa.

Specimens seen. Iran. Tehran province: Kuhe Kalak (Route, Firouzkuh), 4 May 1972, 2550 m, Dini \& Bazargan 13140 (TARI); On Firouzkuh road, Sied abad excouser, 4 June 1972, 2250-2550 m, Dini \& Bazargan 14839 (TARI); On Firouzkuh road, $1990 \mathrm{~m}$, 26 June 2010, Tavakkoli 54236 (FAR); 5 km. Rudehen, Pardis, 1800-1830 m, 29 May 2011, Tavakkoli 54235 (FAR); Haraz road, Rineh, 2050 m, 26 June 2009, Tavakkoli 33882 (FAR), Hraz road, Polour, 2380 m, 23 August 1970, Foroughi 886 (TARI) (Fig. 7).

\section{Taxonomic notes}

G. leiocarpum differs from G. flavum in that it has deep yellow or reddish orange petals with violetbasal spot (vs. yellow, rarely orange petals with reddish or violet basal spot). Ovaries are covered slightly with tubercles near the apex (vs. densely white tubercles).

Siliquas are more or less torulose and attenuate at the apex (vs. neither torulose nor attenuate towards the apex) and 10-15 cm long (vs. $15-25 \mathrm{~cm}$ ) and stem leaves have sinuate to dentate and acute lobes (vs. rounded, obtuse or mucronate lobes) (Cullen, 1965; Mowat, 1964 and Mory, 1979).

Most of the specimens observed have yellow, yellow to orange or reddish orange petals, with or without violet basal spot, which are mostly with yellow margin. The ovaries are covered with white tubercles or glabrous at the base and siliquas are $8-17 \mathrm{~cm}$ long, erect or arcuate, torulose and attenuate towards the apex. But a limited number of specimens were observed to have the petals of yellow or yellow and orange color at the lower part, with or without violet basal spot.

The ovaries are slightly tuberculate at the apex and siliquas are $10-16 \mathrm{~cm}$ long, torulose or not. Stem leaves have rounded or irregular acutely dentate lobes. Therefore, G. leiocarpum cannot be morphologically distinguished from G. flavum; hence, we regard the synonymy of G. leiocarpum with G. flavum. G. oxylobum differs from G. leiocarpum not only in ovary trichomes, but also in filament and leaves shape, petal color and silique characters, as well (Table 1). 

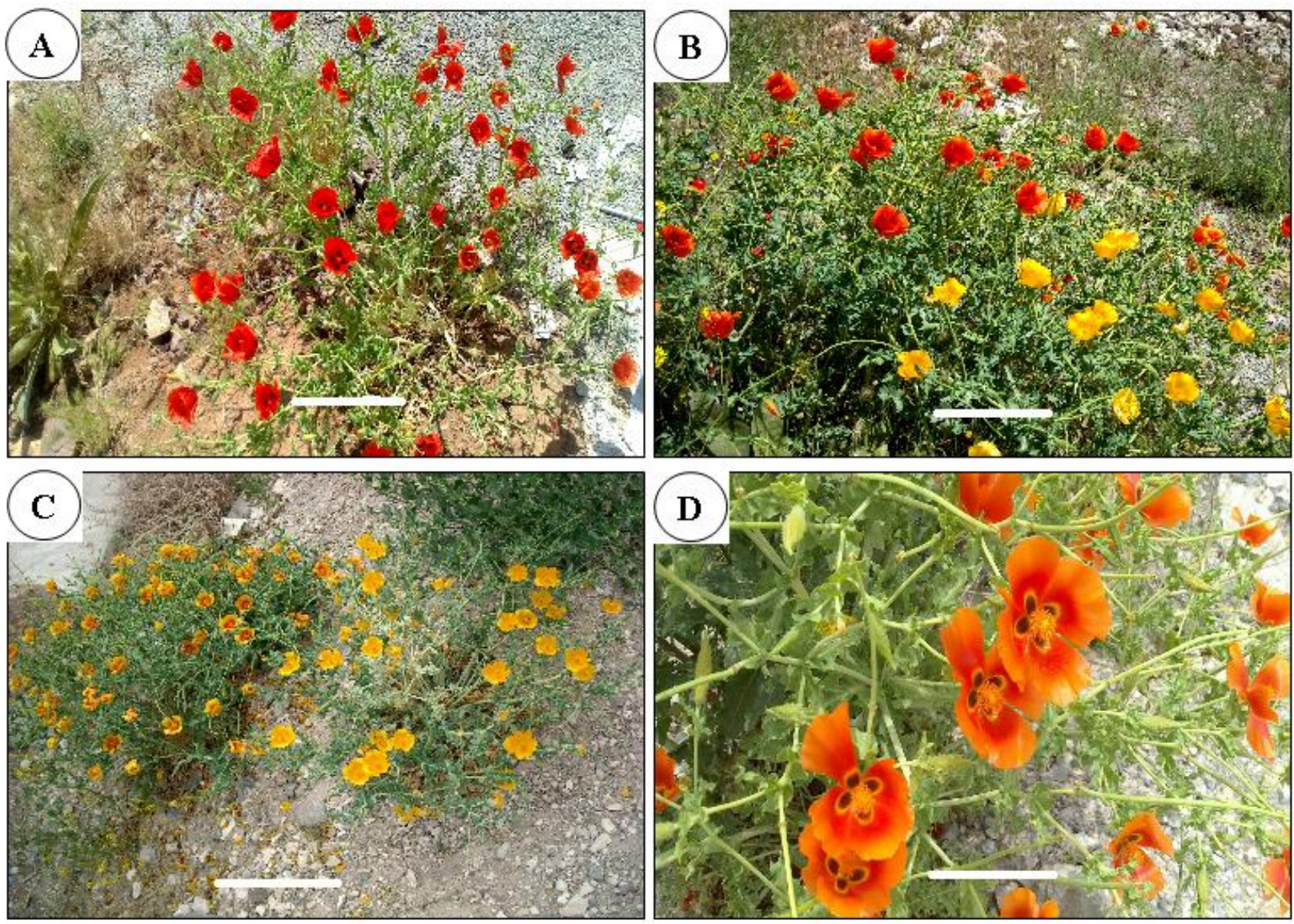

Fig. 5. Photographs of Glaucium flavum (ovaries covered with tubercles). A, B, C: scale bars $=15 \mathrm{~cm} ; \mathbf{D}=\mathrm{scale}$ bars $=5$ $\mathrm{cm}$.

G. elegans Fisch. \& C.A.Mey., Ind. Sem. Hort. Petrop. 1: 29 (1885) (Fig. 6).

Type. Northern Iran. Elburz mountain, Shahrestanak vally, $2200 \mathrm{~m}, 13.6 .1902$, J.F.N. Bornmüller 6087b (MNHN-P-P00739097).

Description. Annual herbs, 5-38 cm high, green or glaucous, with one stem or more. Stems glabrous or with scattered to moderate and crisped hairs, branching from lower part. Basal leaves 2.5-23 $\times$ $0.5-5 \mathrm{~cm}$, with scattered to moderate and crisped hairs along veins, lyrate-pinnatisect to pinnatipartite and sometimes lobed; the segments oblong, triangular, ovate or ovate to oblong, entire or dentate, pinnatifid to pinnatisect; lobes triangular, ovate or obovate, entire or dentate, with apical hairs; the terminal segment trilobed; lobes entire or dentate, obtuse and with apical hairs; petioles $1-4 \mathrm{~cm}$ long, ribbed and broadened at the base; stem leaves 1-15×1-3 cm, with indumentums similar to basal leaves, sessile and semi-amplexicaule; the upper and middle leaves broad ovate or oblong, angulate, lobed or pinnatisect; the segments entire or lobed; lobes triangular or ovate, acute or obtuse and with apical hairs.
Buds 6-26 × 2-5.5 mm, narrow oblong; sepals glabrous or with scattered to rather dense and crisped hairs. Peduncle 0.2-4 cm long, erect. Petals 11-22 $\times$ 6-17 mm, broad obovate, yellow and orange at lower part and with black basal spot. Stamens shorter to longer than ovary; anthers yellow, oblong; filaments slender and monotonic at upper half and broadened at lower part. Ovaries covered with adpressed hairs. Silique 7-16 cm long and $0.5-3 \mathrm{~mm}$ in diameter, torulose, upright, arcuate or contorted at the apex, with nearly patent hairs or glabrous, dehiscing from to base; from base to apex; stigma $2 \mathrm{~mm}$ broad.

Phenology. Flowering early May and fruiting late May to June.

Disribution. Central Asia, Iran, Afghanistan and Pakistan. This species consists of two varieties:

- Plants covered with hairs; silique hairy .var. elegans

- Plants nearly glabrous; silique glabrous or with scattered hairs. .var. bornmulleri 

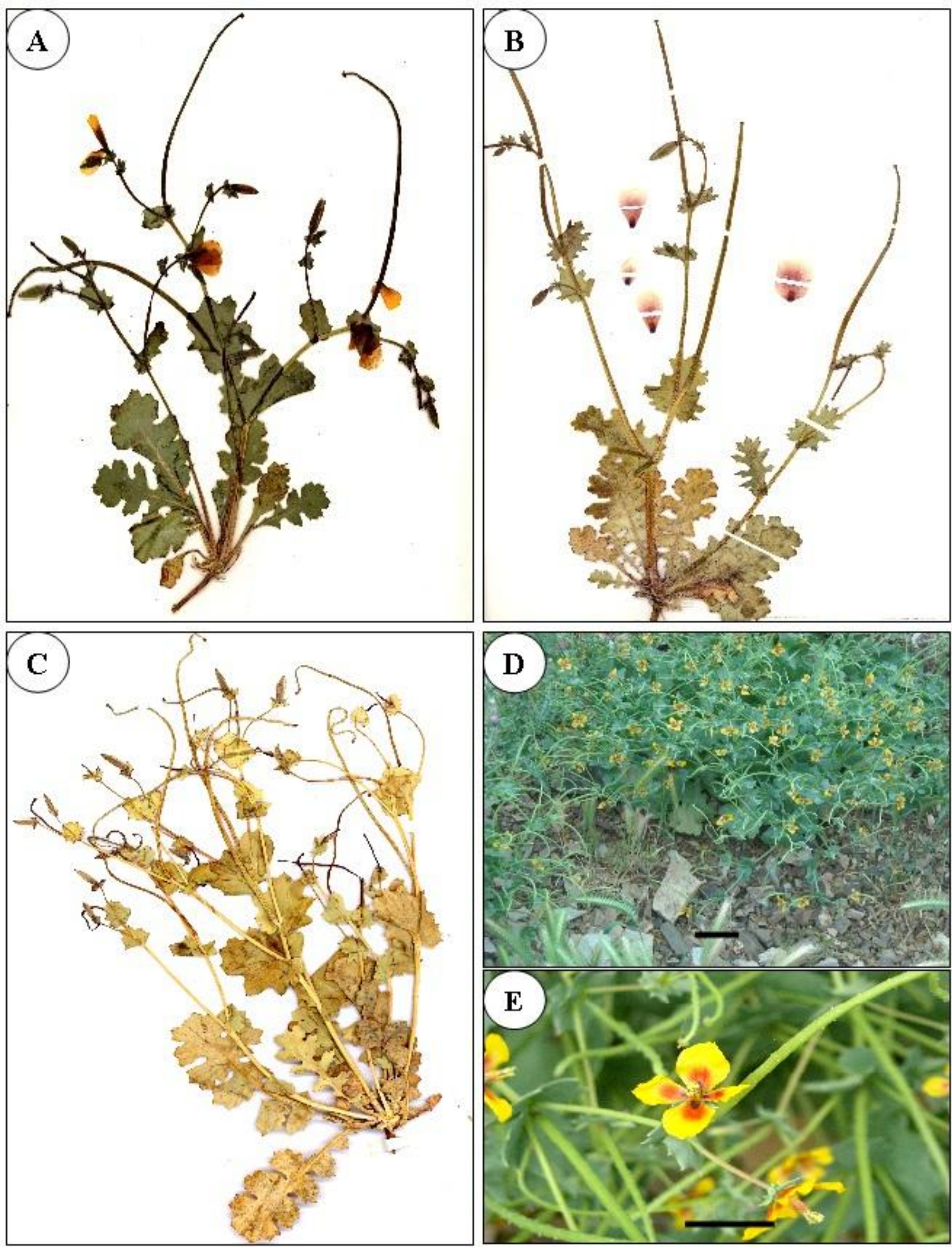

Fig. 6. Photographs of Glaucium elegans. A, B, D, E: scale bars= $2 \mathrm{~cm}$; $\mathbf{C}$ : scale bars: $10 \mathrm{~cm}$. 


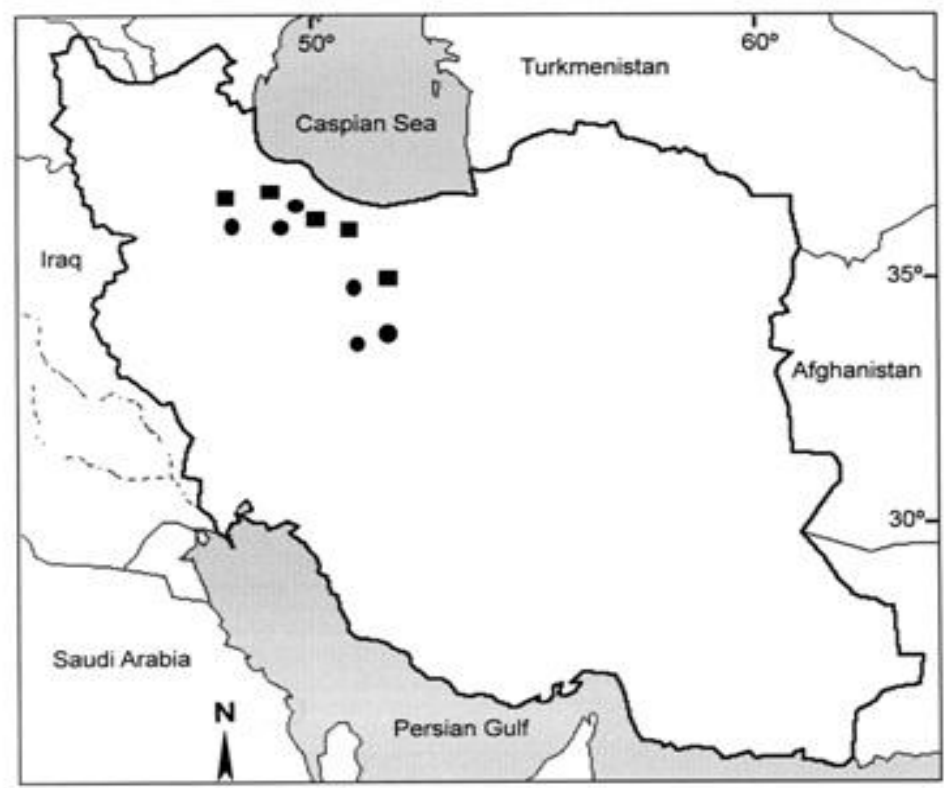

Fig. 7. Distribution map of Glaucium contortuplicatum: var. hirsutum ( $\bullet$ ) and var. contortuplicatum (

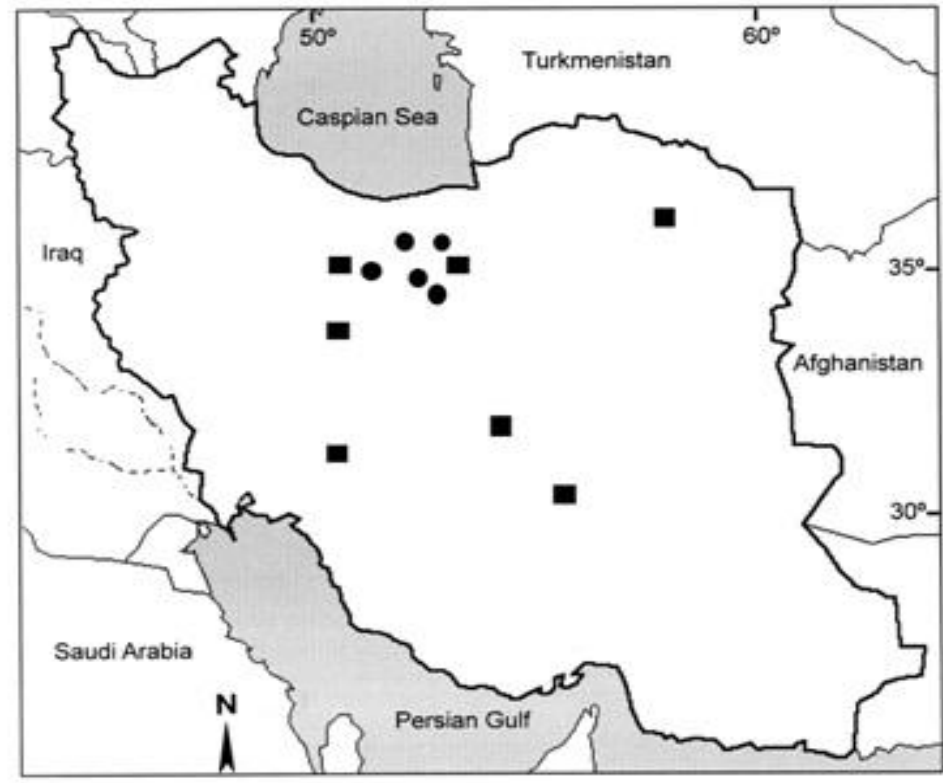

Fig. 8. Distribution map of Glaucium flavum (•) and G. elegans

\section{var. elegans}

Syn. Glaucium elegans var. integerrima Mobayen nom. inval.

Specimens seen. Golestan province: Gorgan, Golestan forest, Dashte Calpush, 920-1000 m, 21 May 1976, Terme \& Matin 5742 (IRAN); Azarbayejan: $62 \mathrm{~km}$ from Ahar on the road to Tabriz, 1400 m, 12 June 1976, Assadi \& Massoumi 2057 (TARI); Khorassan province: Robat sefid, 27 May 1948, 1800-2200 m, Rechinger et al. 5755 (4428E) (IRAN); Kerman province: Kerman, 1700 m, 12 May 1969, Babakhanlou 24019 (TARI); Semnan province: Touran protected area, $4 \mathrm{~km}$ to
Delbaro the road, 1250 m, 8 May 1978, Freitag \& Jadidi 28943 (TARI); Tehran province: Karaj, Kuh Dashteh, 2200 m, 16 June 1972, Riazi 4470 (TARI) (Fig. 8).

var. bornmulleri Fedde

Specimens seen. Iran. Golestan province: Gorgan, Azad shahr, Bojnourd, $79 \mathrm{~km}$ Azad shahr, 950 m, 6 June 1975, Terme 5745 (IRAN); Tehran province: $22 \mathrm{~km}$ from Tehran on the Garmsar road, Khatoun abad, 1010 m, 4 June 1972, Mousavi \& Amin 14862 (TARI). 


\section{Taxonomic remarks}

G. elegans var. integerrima Mobayen was reported from NW Iran based on dentate or lobed leaves and yellow and pink petals (Mobayen, 1985). G. elegans was reported by Cullen (1966), Popov (1937) and Fedde (1909) for having pinatifid or pinnatisect radical leaves; the stem leaves nearly ovate, sinuate to dentate or rarely entire and having yellow petals, red in the middle part and with black basal spot. Among specimens studied, some were observed which had lobed or pinnatisect to pinnapartite basal and stem leaves. Some specimens also had lobed or dentate stem leaves and pinnatisect basal leaves. Their petals were yellow to orange (with black basal spot) in fresh stage but pinkish in dry stage. Therefore, the separation of var. integerrima from the type variety cannot be justified.

\section{ACKNOWLEDGEMENT}

The author is grateful to professor Mostafa Assadi for his critical comments and valuable suggestions on the manuscript. I also thank the curators of the TARI and IRAN herbaria for providing herbarium materials.

\section{REFERENCES}

Barthlott, W., Neinhuis, C., Cutler, D., Ditsch, F., Meusel, I., Theisen, I. and Wilhelmi, H. 1998. Classification and terminology of plant epicuticular waxes. - Bot. J. Linn. Soc. 126: 237-260.

Boissiera, E. 1867. Flora orientalis, vol. 1: 119-123. H. Georg, Genevae.

Cullen, J. 1965. Glaucium. - In Davis, P.H. (ed.), Flora of Turkey and the east Aegean Islands. vol. 1: 214-217. - Edinburgh University Press, Edinburgh.

Cullen, J. 1966. Glaucium. In: Rechinger, K.H. (ed.), Flora Iranica, no. 34: 2-7 - Akad. Druck. Verlagsanstalt, Graz.

Fedde, F. 1909. Glaucium. In: Engler, A. (ed.), Das Pflanzenreich, vol. 4 (104): 221-238. - W. Engelmann, Leipzig .

Gran, A., Sharifnia, F. 2008. Micromacromorphological studies of the genus Glaucium (Papaveraceae) in Iran. - Iran. J. Bot. 14 (1): 23 -38 .

Hoot, S.B., Kadereit, J.W., Blattner, F.R., Jork, K.B., Schwarzbach, A.E. and Crane, P.R. 1997. Data congruence of the Papaveraceae s.
1. based on four data sets: atpB and rbcL sequences, trnK restriction sites, and morphological characters. - Syst. Bot. 22 (30) 575-590.

Kadereit, J.W. 1993. The families and genera of vascular plants, Kubitzki, K. Rohwer, J.C. \& Bittrichotteidedelberg (eds.). - Springer, Verlag Berlin. 663 pp.

Mobayen, S. 1985. Glaucium. In: Flora of Iran, vascular plants, vol. 3: 154-170. - Tehran University Tehran.

Mory, B. 1979. Beitragezur Kenntnis der Sippenstruktur der Gattung Glaucium Miller Papaveraceae). - Feddes Repert. 39 (9-10): 499595.

Mowat, A.B. 1964. Glaucium. In: Tutin, T.G., Burges, N.A., Chater, A.O., Edmondson, J.R., Heywood, V.H., Moore, D.M., Valentine, D.H., Walters, S.M. and Webb, D.A. (eds), Flora Europaea, vol. 1. - Cambridge University Press, Cambridge.

Parsa, A. 1986. Glaucium. In: Flora of Iran, vol. 2: 429-446. - Ministry of Culture and Higher Education of Islamic Republic of Iran, Tehran.

Popov, M.G. 1937. Glaucium. In Schischkin, B.K. Flora of the USSR, vol. 7: 447-455. Akademi Nauk SSSR, Moskva-Leningrad.

Takhtajan, A. 2009. Glaucium. In: Flowering Plants. second edition: 96-97. - Springer, New York.

Van Cotthen, W. 1970. A classification of stomatal types. - Bot. J. Linn. Soc. 63: 235-246.

$* * * * *$

Tavakkoli, Z. 2016. Notes on some species of the genus Glaucium (Papaveraceae) in Iran. - Nova Biol. Reperta 3 (2): 167-176. 